\title{
Axis determination by inhibition of Wnt signaling in Xenopus
}

\author{
Keiji Itoh and Sergei Y. Sokol ${ }^{\mathbf{1}}$ \\ Department of Microbiology and Molecular Genetics, Harvard Medical School and Molecular Medicine Unit, Beth Israel \\ Deaconess Medical Center, Boston, Massachusetts 02215 USA
}

The Wnt family of secreted polypeptides participate in a variety of developmental processes in which embryonic polarity is established. To study a role for Wnt ligands in vertebrate axis determination, we interfered with Wnt signaling in the embryo using the extracellular domain of Xenopus Frizzled 8 (ECD8), which blocks Wnt-dependent activation of a target gene in Xenopus ectodermal explants. Expression of ECD8 in ventral blastomeres resulted in formation of secondary axes containing abundant notochord and head structures. These results suggest that Wnt signaling is required to maintain ventral cell fates and has to be suppressed for dorsal development to occur.

[Key Words: Dorsoventral axis; organizer; Frizzled; mesoderm; BMP]

Received June 8, 1999; revised version accepted July 21, 1999.

Initial specification of dorsoventral axis in vertebrate embryos occurs through the formation of the dorsal signaling center, or Spemann organizer, and is thought to involve TGF $\beta$, FGF, and Wnt signal transduction (for review, see Harland and Gerhart 1997). The Wnt signaling pathway results in stabilization of $\beta$-catenin by signals from the Frizzled receptors and the cytoplasmic protein Dishevelled, which antagonizes glycogen synthase kinase 3 (GSK3) and Axin (Cadigan and Nusse 1997; Sokol 1999). Signaling by maternal $\beta$-catenin in complex with the T-cell factor (TCF) family of transcriptional regulators activates several dorsal region-specific target genes and is among the earliest steps leading to induction of the organizer (Cadigan and Nusse 1997; Harland and Gerhart 1997; Moon et al. 1997). Although several secreted Wnt proteins induce a secondary body axis when overexpressed in ventral blastomeres of Xenopus embryos (Sokol et al. 1991; Moon et al. 1997; Sokol 1999), dominant-negative inhibitors of Xwnt8 and Dishevelled fail to suppress organizer-specific genes in the primary axis (Hoppler et al. 1996; Sokol 1996). These experiments indicate that for dorsal development, maternal $\beta$-catenin signaling may be activated intracellularly, in the absence of a Wnt ligand.

Whereas $\beta$-catenin signaling is essential for induction of the organizer (Heasman et al. 1994), it is less clear whether Wnt ligands function in the maintenance of the dorsal and ventrolateral embryonic domains at later stages of development. Xwnt5a (Moon et al. 1993) and $X w n t 8 b$ (Cui et al. 1995) are expressed in the early embryo, but their developmental functions are unknown. Xwnt11, Xwnt3a, and a Xenopus homolog of frizzled 8

${ }^{1}$ Corresponding author.

E-MAIL ssokol@caregroup.harvard.edu; FAX (617) 667-2913.
$(X f z 8)$ are all present in the dorsal marginal zone at gastrula stages and were proposed to participate in dorsal development (Ku and Melton 1993; McGrew et al. 1997; Deardorff et al. 1998; Itoh et al. 1998). In contrast, Xwnt8 mRNA is present in the ventrolateral region (Christian et al. 1991). Consistent with the idea that Xwnt8 functions to maintain ventrolateral mesoderm formation, ectopic overexpression of Xwnt8 after the midblastula transition leads to inhibition of notochord and head development (Christian and Moon 1993). However, a number of efficient Xwnt8 antagonists, including secreted Frizzled-related proteins (FRPs) and Dickkopf-1 (Dkk-1) (Hoppler et al. 1996; Finch et al. 1997; Leyns et al. 1997; Mayr et al. 1997; Salic et al. 1997; Glinka et al. 1998; Xu et al. 1998), failed to trigger dorsal development in ventral blastomeres, suggesting that Xwnt8 is not required for the maintenance of ventral fates. Nevertheless, the dominant-negative form of Xwnt8 and some FRPs inhibited myoD expression in the marginal zone (Hoppler et al. 1996; Leyns et al. 1997; Salic et al. 1997; Wang et al. 1997a), implicating Xwnt8 or related Wnt products in muscle development.

To further evaluate the involvement of Wnt ligands in dorsoventral axis determination, we interfered with Wnt signaling using ECD8, the extracellular domain of $\mathrm{Xfz} 8$ (Itoh et al. 1998; Deardorff et al. $\overline{1}$ 1998). E $\bar{C} D 8$ contains a conserved cysteine-rich domain and resembles FRPs that were shown to bind and inactivate Wnt ligands (Finch et al. 1997; Leyns et al. 1997; Mayr et al. 1997; Rattner et al. 1997; Salic et al. 1997; Wang et al. 1997a; Xu et al. 1998). Consistent with its potential function as a Wnt inhibitor, ECD8 blocked the activity of several Wnt ligands in ectodermal explants. Our data show that in contrast to previously described FRPs, ECD8 induced a complete secondary axis when overexpressed in ventral blasto- 
meres. These results suggest that some Wnt ligand(s) function to maintain ventral cell fate and these ligands have to be suppressed to allow dorsal development to occur.

\section{Results and Discussion}

\section{ECD8 antagonizes Wnt signaling}

ECD8 contains the extracellular domain of Xfz8 (Itoh et al. 1998) but lacks the transmembrane and cytoplasmic regions that are required for transmitting the signal to downstream components of the Wnt pathway (Cadigan and Nusse 1997). Because FRPs have a similar structure and have been demonstrated to block Wnt activities, ECD8 is also predicted to function as a Wnt antagonist.

To examine whether ECD8 interferes with Wnt signaling, we coexpressed ECD8 with different Wnt ligands in animal pole ectoderm and analyzed Wnt-dependent activation of the organizer marker $X n r 3$, which is a direct target of Wnt signaling (McKendry et al. 1997). ECD8 mRNA completely suppressed induction of Xnr3 by all tested Wnt proteins (Fig. 1), including Xwnt2b, Xwnt3a, Xwnt8, and a combination of Xwnt5a with Xfz8 that allows detection of the axis-inducing activity of Xwnt5a (Itoh et al. 1998). In contrast, Frzb, a member of the FRP family (Leyns et al. 1997; Wang et al. 1997a,b),
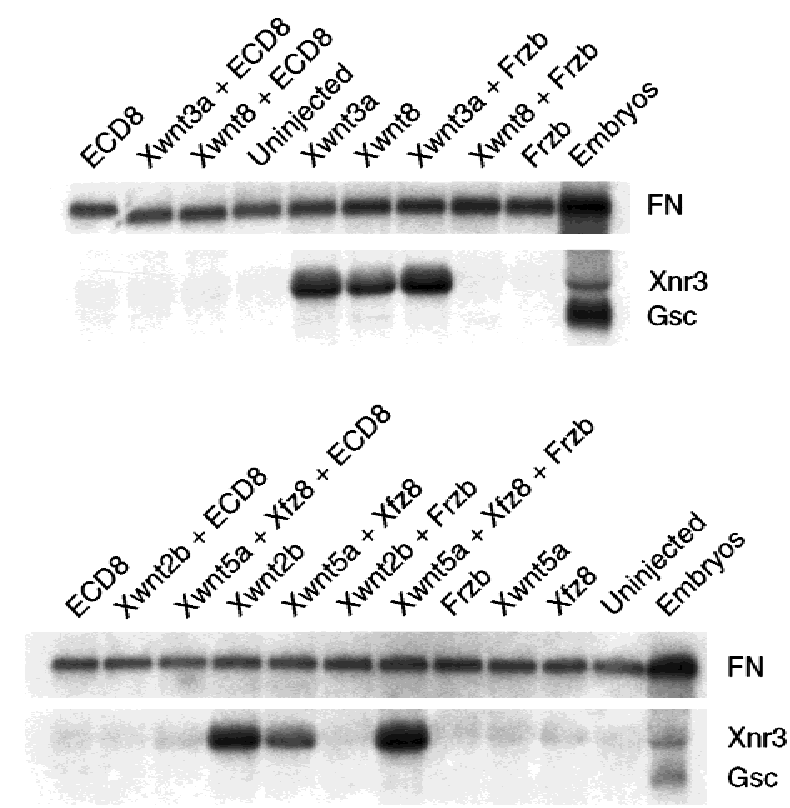

Figure 1. ECD8 is a potent Wnt inhibitor. Two-cell embryos were injected into animal pole with ECD8 (2 ng), frzb (2 ng), Xwnt3a (5 pg), Xwnt8 (2.4 pg), Xwnt2b (5 pg), Xwnt5a (0.6 ng), and $X f_{z} 8(0.6 \mathrm{ng}) \mathrm{mRNA}$, or in combination as indicated. Animal cap explants were prepared from the injected embryos when sibling control reached stage 8 and cultured until control embryos reached stage 10.5, at which time total RNA was isolated for Northern analysis. Each gel lane contains RNA isolated from ten explants or two embryos. Xnr3 and gsc are organizer markers. fibronectin $(F N)$ serves as a control. was not able to inhibit the activity of Xwnt3a and Xwnt5a (Fig. 1). These results indicate that ECD8 is an effective inhibitor of a wide range of Wnt ligands and can be used to assess the role for endogenous Wnt ligands in embryogenesis.

\section{The effects of ECD8 on embryogenesis}

To inhibit endogenous Wnt signaling, ECD 8 mRNA was microinjected into ventrovegetal or dorsovegetal blastomeres of four- to eight-cell embryos. Embryos that were injected with ECD 8 mRNA in a single ventral blastomere developed secondary axes containing pronounced anterior and dorsal structures (Fig. 2A-C). The induced axes were short but contained eyes and large cement glands, which were often fused with the primary axis (Table 1). Histological analysis demonstrated that induced secondary axes included well-differentiated notochord, somites, and neural tissue with eyes and cement glands in all cases examined ( $n=30$; Fig. $2 \mathrm{~B}, \mathrm{C})$. Although the eyes were not recognized clearly externally, tissue sections revealed differentiated retina and lens. The effect of ECD 8 mRNA was dose dependent; at 1-2 ng of ECD 8 mRNA, axes with anterior structures were induced in $66 \%$ of injected embryos $(n=253)$, whereas at $0.1-0.3 \mathrm{ng}$ of mRNA, the frequency of secondary axes was reduced to $5 \%(n=81)$. Ventral injections of a control BH1 mRNA, or mRNAs encoding Frzb (Leyns et al. 1997) and FrzA (Xu et al. 1998; data not shown) did not induce secondary axes at the same doses, indicating that the effect of ECD8 is specific (Table 1; Fig. 3). These results suggest the existence of Wnt ligand(s) that function to maintain ventral cell fates and suppress dorsal development in ventrolateral blastomeres.

The majority of embryos that were injected with ECD 8 mRNA in dorsal blastomeres had shortened trunk and tail, enlarged cement gland, and deficient eyes (Fig. 2D; Table 1). Histological analysis revealed a short and wide notochord and neural tissue (Fig. 2E), indicating impaired morphogenetic movements. In support of this view, ECD8 blocked elongation of animal cap explants in response to the mesoderm-inducing factors FGF and activin (data not shown). These effects of ECD8 on axis extension and anterior development are similar to the activities described previously of the dominant-negative (dn) Dishevelled (Sokol 1996), dnXwnt8 (Hoppler et al. 1996), and some Frizzled-related proteins (Leyns et al. 1997; Salic et al. 1997; Wang et al. 1997a; Deardorff et al. 1998). They are consistent with the idea that Wnt signaling is involved in the control of convergent extension movements, the major driving force for elongation of the embryo during gastrula and neurula stages (Keller 1991).

\section{Cells overexpressing ECD8 predominantly contribute to secondary head structures}

To determine the developmental fate of cells that contribute to the secondary axis induced by ECD8, we injected ECD8 RNA together with lacZ RNA as a lineage 
Figure 2. Developmental effects of ECD8. ECD 8 mRNA (1-2 ng) was injected into one ventrovegetal blastomere $(A-C)$ or into two dorsovegetal blastomeres $(D, E)$ at the four- to eight-cell stage. External morphology of injected embryos $(A, D)$. (Arrowheads) Induced secondary axes; (arrows) enlarged or fused cement glands. $(D)$ An uninjected sibling embryo (stage 33) is shown at bottom. Histological analysis of injected embryos in transverse $(B, C)$ and sagittal $(E)$ sections. $(F)$ Transverse section of a control sibling embryo. $\left(1^{\circ}\right)$, primary axis; $\left(2^{\circ}\right)$ secondary axis; (nt) neural tissue; (e) eye; (cg) cement gland; (nc) notochord; (mu) muscle. Scale bar, $400 \mu \mathrm{m}$ for $E$ and $200 \mu \mathrm{m}$ for $B, C$, and $F$.
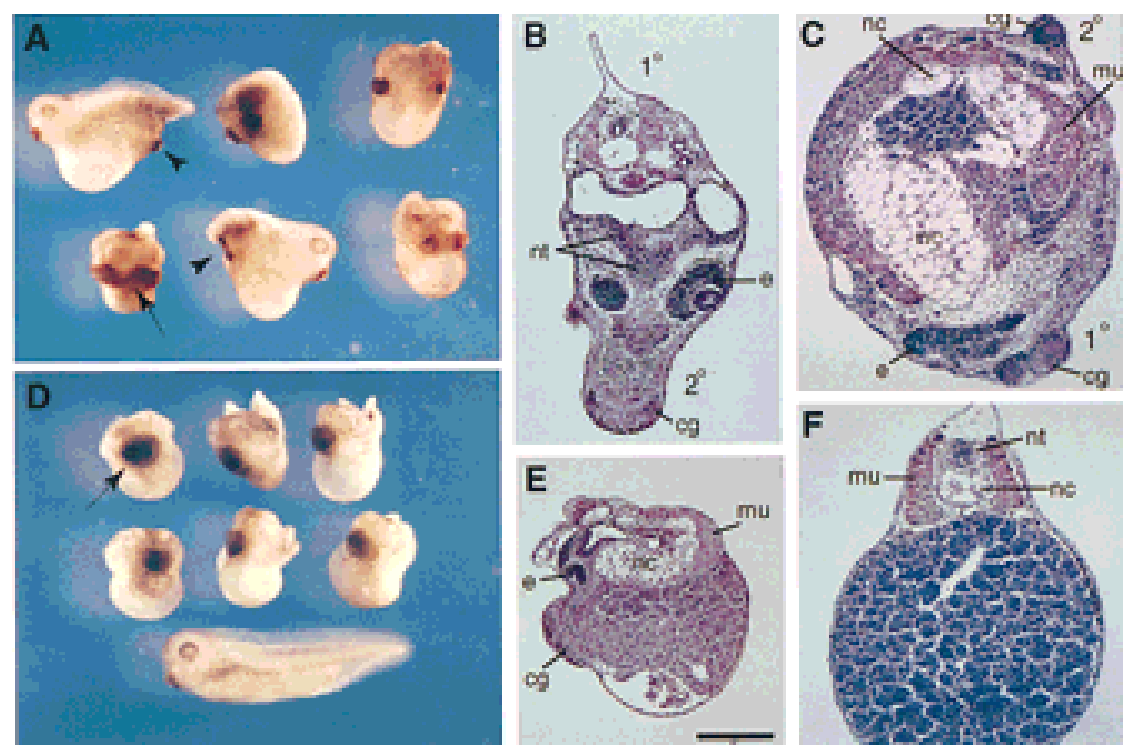

tracer into a ventral blastomere. Injected embryos were allowed to develop to tadpole stages, and tissue distribution of $\beta$-galactosidase activity was analyzed in whole mounts and in tissue sections (Fig. 3). frzb and lacZ RNAs were used as a control. If ECD8 were capable of inducing an organizer, ECD8-expressing cells would be expected to contribute to anterior endomesoderm and axial mesoderm, as reported for other axis-inducing molecules, such as Xwnt8, Noggin, Chordin, BVg1, Dishevelled, and $\beta$-catenin (Smith and Harland 1991, 1992; Sokol et al. 1991, 1995; Thomsen and Melton 1993; Sasai et al. 1994; Guger and Gumbiner 1995). Unexpectedly, after coinjection of ECD8 and lacZ RNAs, $\beta$-galactosidase activity was predominantly found in the cement gland, neural tissue, and epidermis of the secondary head, although we cannot exclude limited contribution to anterior endomesodermal tissues (Fig. 3A,C; data not shown). In most cases, secondary notochord remained unlabeled, suggesting that it is induced by ECD8-containing cells. In control embryos, cells overexpressing Frzb occupied lateral plate mesoderm and epidermis and occasionally contributed to the neural tissue of the primary axis or somites (Fig. 3B,D; data not shown). This distribution of $\beta$-galactosidase activity roughly corresponded to that in embryos injected into the same location only with lacZ RNA (data not shown). Our results demonstrate that ventrolateral blastomeres expressing ECD8 develop head neuroectoderm and trigger non-cell autonomous induction of ectopic notochord. Thus, ECD8 appears to induce a complete axis by a mechanism that is quite different from the mechanism of axis induction by known axial inducers.

\section{ECD8 and Xwnt8 activate organizer markers via different molecular mechanisms}

Because dorsal axial development is normally preceded by the formation of the organizer, we tested if overexpression of ECD8 leads to induction of organizer markers in ventral blastomeres. Xwnt8 mRNA, which is known to activate an ectopic organizer (Smith and Harland 1991; Sokol et al. 1991), induced all tested organizer

Table 1. The effects of ECD8 and frzb RNAs on axial development

\begin{tabular}{|c|c|c|c|c|c|c|c|c|}
\hline $\begin{array}{l}\text { Injected } \\
\text { RNA }\end{array}$ & $\begin{array}{l}\text { Injection } \\
\text { site }\end{array}$ & $\begin{array}{l}\text { Total no. } \\
\text { injected }\end{array}$ & $\begin{array}{l}\text { Normal } \\
\text { body } \\
\text { axis }\end{array}$ & $\begin{array}{l}\text { Secondary } \\
\text { axis with } \\
\text { cement gland }\end{array}$ & $\begin{array}{l}\text { Enlarged cement } \\
\text { gland with defects } \\
\text { in axis extension }\end{array}$ & $\begin{array}{l}\text { Partial axis } \\
\text { without } \\
\text { cement gland }\end{array}$ & $\begin{array}{l}\text { Axis } \\
\text { extension } \\
\text { defects }\end{array}$ & $\begin{array}{l}\text { Other } \\
\text { defects }\end{array}$ \\
\hline ECD8 & VV & 253 & 14 & 75 & 64 & 28 & 66 & 6 \\
\hline ECD 8 & DV & 265 & 4 & 1 & 176 & 1 & 82 & 1 \\
\hline BH1 & VV & 165 & 157 & 0 & 0 & 0 & 1 & 7 \\
\hline BH1 & DV & 48 & 39 & 0 & 0 & 0 & 0 & 9 \\
\hline frzb & VV & 139 & 25 & 0 & 0 & 0 & 34 & 80 \\
\hline$f r z b$ & DV & 71 & 13 & 0 & 3 & 0 & 44 & 11 \\
\hline
\end{tabular}

ECD8, BH1, or frzb mRNAs (1 ng each) were injected into one ventrovegetal (VV) blastomere or two dorsovegetal (DV) blastomeres of four- to eight-cell embryos. External morphological changes were assessed at stage 30-39. Ventral overexpression of ECD8 often resulted in the fusion of primary and secondary axes, which is categorized as an enlarged cement gland with defects in axis extension. Other defects included embryos with kinked axis, microcephaly, and gastrulation defects. Many embryos ventrally injected with frzb RNA developed kinked tails and were scored as containing other defects. 
A

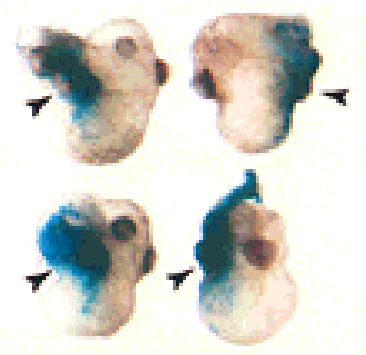

B

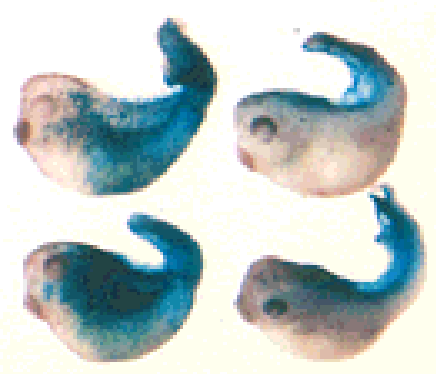

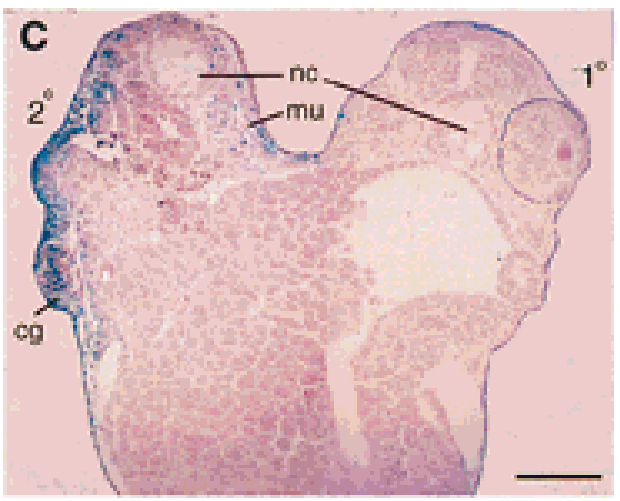

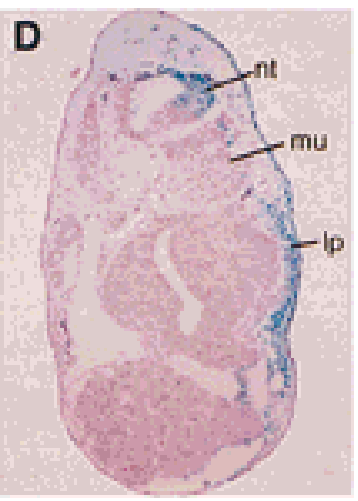

Figure 3. Lineage tracing of embryos overexpressing $E C D 8$ and $f r z b$ RNAs. Subequatorial region of a ventral blastomere of four cell embryos was injected with $1 \mathrm{ng}$ of $E C D 8(A, C)$ or frzb $(B, D)$ mRNA together with $0.5 \mathrm{ng}$ of lacZ mRNA. When control siblings reached stage 39 , the injected embryos were fixed and stained for $\beta$-galactosidase activity. (A) Staining is predominantly observed in the secondary head (arrowheads). (B) Embryos injected with Frzb mRNA developed kinked tails that were stained on the injected side (left). The uninjected side of two other embryos is shown right. $(C)$ Transverse section of an embryo injected with ECD8 RNA reveals $\beta$-gal staining in neural tissue, cement gland, and epidermis of the secondary head, but notochord and somites remain unstained. $(D)$ Transverse section of an embryo injected with frzb RNA shows stained lateral plate mesoderm, neural tube, and epidermis on one side. Abbreviations are as in Fig. 2, except for (lp) lateral plate mesoderm. Scale bar in $C$ (also refers to $D$ ), $200 \mu \mathrm{m}$. markers, including goosecoid (gsc), Xotx2, Xnr3, chordin, cerberus, frzb, and Xlim1 and down-regulated ventrolateral markers $P V .1$ and $X w n t 8$ (Fig. 4A). In contrast, ECD8 did not significantly activate organizer genes in ventrovegetal cells by the beginning of gastrulation (Fig. 4A). However, by the late gastrula stage, ECD8 selectively induced several dorsal markers including Xotx2, chordin, Xlim1, and myoD, but not XANF1, frzb, or cer- berus, and down-regulated the expression of $P V .1$ but not Xwnt8 (Fig. 4B). The delayed appearance of induced markers suggests that ECD8 alters cell fates only at gastrulation, after the organizer has been induced. Nevertheless, by neurula stages, ECD8 induced dorsal and anterior markers including NCAM, Xotx2, XAG1, and muscle actin (Fig. 4C), corroborating histological data. The induction of muscle by ECD8 was further supported
A

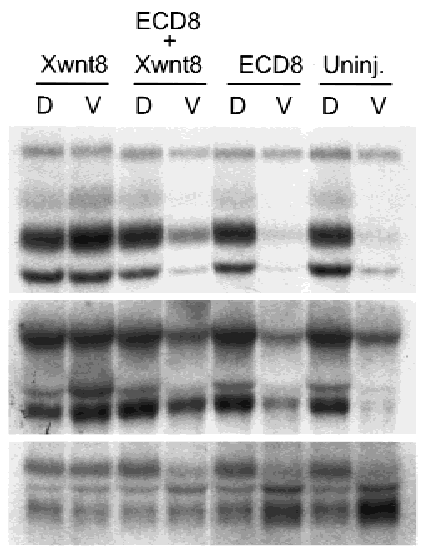

B

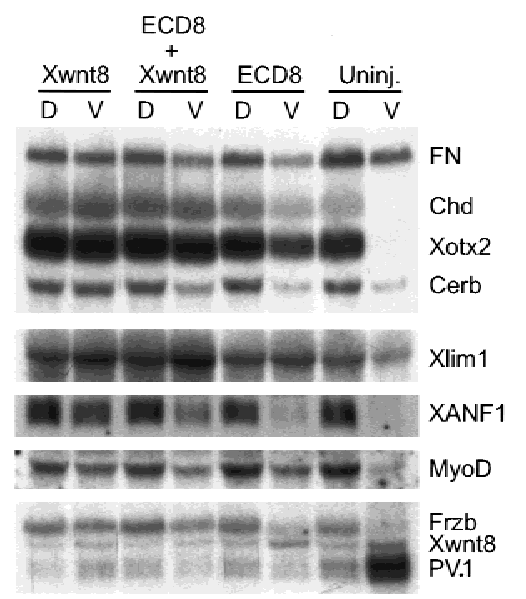

C

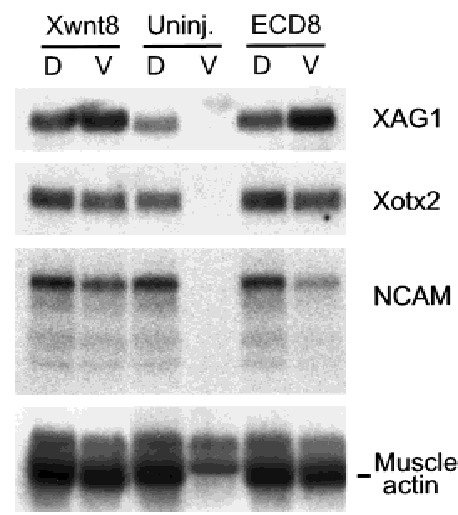

Figure 4. Selective effect of ECD8 on marginal zone markers. Two ventrovegetal blastomeres of four- to eight-cell embryos were injected with 5 pg of Xwnt 8 mRNA, 2 ng of ECD 8 mRNA, or with both mRNAs as indicated. Dorsal and ventral halves were dissected at the beginning of gastrulation and collected immediately $(A)$ or cultured until stage $12.5(B)$ or stage $16(C)$ for Northern analysis. chordin (Chd), cerberus (Cerb), Xlim1, Xnr3, gsc, and frzb are organizer markers; XANF1 and Xotx2 are dorsal marginal zone and anterior ectoderm markers; $X w n t 8$ and $P V .1$ are ventrolateral markers; myoD is an early marker for somites; XAG1 is a cement gland marker; NCAM and XIF3 are general neural markers. fibonectin $(F N)$ serves as a loading control. The two bands at top revealed by the cardiac actin probe correspond to cytoskeletal actin and reflect loading $(C)$; the band at bottom is muscle specific. 
by whole-mount staining with 12/101 muscle-specific antibodies (data not shown). These results suggest that exogenous Xwnt8 and ECD8 stimulate dorsal development via different molecular pathways and operate at different times during embryogenesis. In agreement with this view, both GSK3 and a dominant-negative form of Xenopus Dishevelled strongly inhibited the ability of Xwnt8 to induce a second axis but did not suppress the axis-inducing activity of ECD8 (data not shown).

ECD8 also reduced the expression of Xwnt8-inducible markers, including cerberus, Xotx2, chordin, Xlim1, gsc, $X n r 3$, and $f r z b$, at early gastrula stage (Fig. 4A), confirming that ECD8 interferes with Wnt signaling not only in animal cap cells, but also in ventrovegetal cells. However, the expression of Xotx2, chordin, and Xlim1 recovered by late gastrula stage (Fig. 4B), consistent with the ability of ECD8 to activate the same markers in the absence of exogenous Xwnt8. These results further support the idea that ECD8 induces secondary axes in ventrovegetal cells by interfering with Wnt signaling at later stages.

\section{The effect of ECD8 on BMP signaling}

Although the structure of ECD8 predicts that it is a specific inhibitor of Wnt signaling, it down-regulates the expression of $P V .1$ (Fig. 4B), an early target gene for bone morphogenetic protein (BMP) signaling (Ault et al. 1996). Because inhibition of BMP4 leads to partial secondary axis formation (Graff et al. 1994; Suzuki et al. 1994), and BMP activity is suppressed in dorsal tissues during gastrulation, we suspected that ECD8 might also modulate the BMP pathway. We therefore assessed whether inhibition of BMP signaling by ECD8 occurs at the level of ligand-receptor interactions or represents an indirect consequence of blocking Wnt ligands.
Several observations indicate that ECD8 does not directly inhibit BMP4 signaling. First, whereas the truncated BMP receptor (tBR) completely blocked BMP4-dependent PV.1 and Xbra expression in animal cap cells, ECD8 had only a marginal effect at stage 10.5 (Fig. 5A). By stage 12.5 , however, ECD8 down-regulated PV.1 (Fig. $5 \mathrm{~A})$, suggesting that Wnt signaling is critical for the maintenance rather than initiation of $P V .1$ expression. Second, neural markers, such as NCAM and XIF3, were induced by $\mathrm{tBR}$, consistent with the idea that inhibition of BMP signaling leads to neural induction (De Robertis and Sasai 1996). In contrast, ECD8 did not activate neural markers at the dose that is effective in complete axis induction (Fig. 5B). Third, we found that ECD8 inhibited ligand-independent signaling from the constitutively active BMP4 receptor (CABR; Candia et al. 1997). A BMP4responsive reporter construct, consisting of the luciferase gene fused to the Xvent2 promoter sequences (Xvent2-luc), is activated by CABR independently of BMP ligands (Fig. 5C; Candia et al. 1997). This transcriptional activation of Xvent2-luc was inhibited weakly, but significantly, by ECD8 (Fig. 5C). Thus, the effect of ECD8 on PV.1 and Xvent2 is likely to be a consequence of blocking Wnt ligands, rather than BMP ligands, because it can occur downstream of BMP ligand/receptor interactions.

\section{ECD8 does not induce dorsal markers in animal caps but modifies their responses to the mesoderm inducing factors FGF and activin}

Because ECD8 appears to stimulate dorsoanterior ectoderm (head) development in injected embryos, we wanted to assess whether ECD8 can induce head formation in ectodermal explants, either untreated or treated with mesoderm inducing factors. Although ECD8 RNA
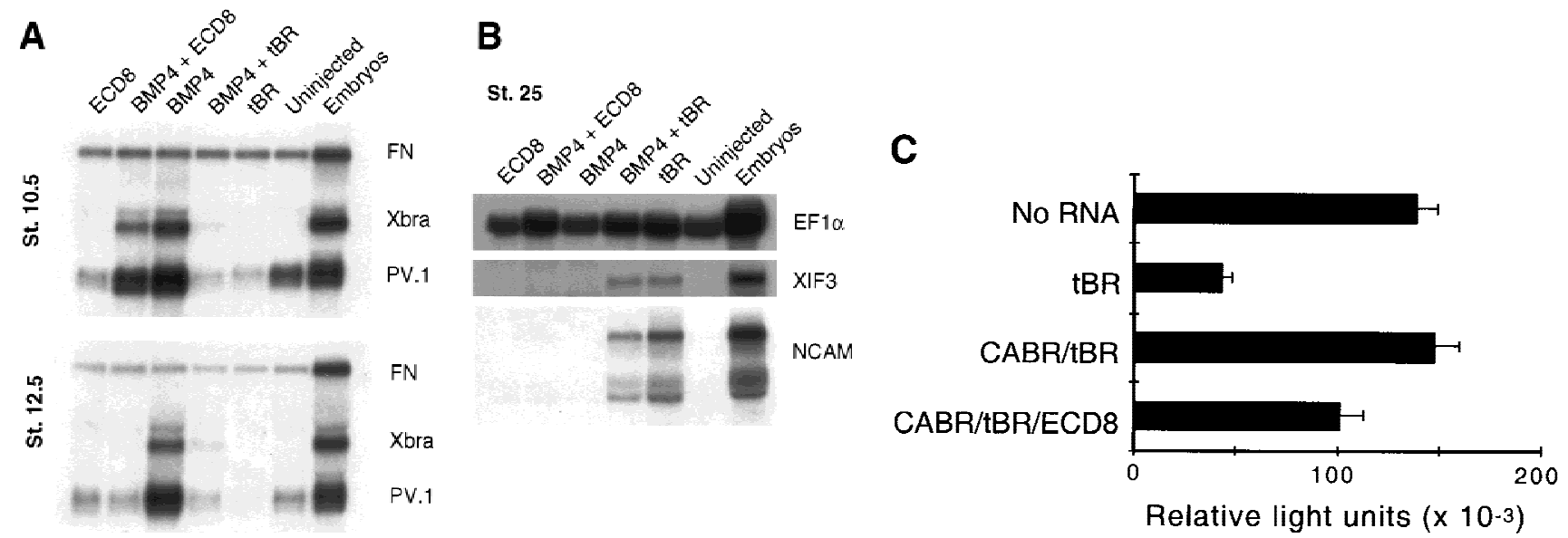

Figure 5. The effect of ECD 8 on BMP signaling. Animal caps were prepared as in Fig. 1 from embryos injected with 2 ng of $E C D 8$, $0.4 \mathrm{ng}$ of $B M P 4$, or $2 \mathrm{ng}$ of $t B R$ mRNA as indicated. The animal caps were harvested when control siblings reached stage $10.5(A), 12.5$ $(A)$, or $25(B)$ for Northern analysis. fibronectin $(F N)$ and EF1 $\alpha$ are loading controls. Xbra is a general marginal zone marker; $P V .1$ is a ventrolateral marker; XIF3 and NCAM are pan-neural markers. $(C)$ The effect of ECD8 on signaling from CABR. Each blastomere of four-cell embryos was injected with $20 \mathrm{pg}$ of Xvent2-luc DNA and $0.5 \mathrm{ng}$ of $t B R, C A B R$, and ECD 8 RNAs as indicated. Luciferase activity was measured in injected embryos at stage 10. Experimental data are expressed as the means from triplicate samples $+/-$ standard deviations. 
A

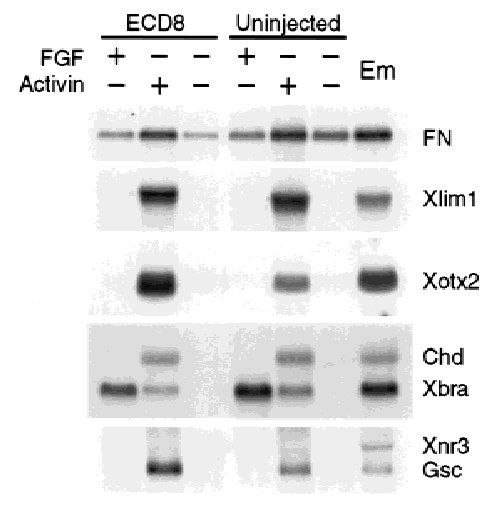

B

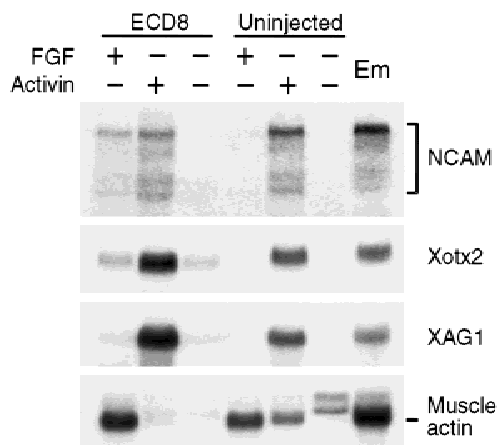

Figure 6. The effect of ECD8 on ectodermal explants treated with mesoderm-inducing factors. Animal caps were isolated at the midblastula stage from uninjected embryos and from embryos injected with $2 \mathrm{ng}$ of ECD $8 \mathrm{mRNA}$. Explants were treated with $100 \mathrm{ng} / \mathrm{ml} \mathrm{bFGF}$ or $5 \mathrm{ng} / \mathrm{ml}$ activin and cultured until stage $10.5(A)$ or stage $25(B)$ for Northern blot analysis. Molecular markers are described in legends to Figs. 1, 4, and 5. (Em) Sibling embryos.

efficiently induced secondary axes when injected ventrally, at the same doses it failed to activate the organizer markers chordin, Xnr3, Gsc, Xlim1, and Xotx2, musclespecific actin, or NCAM in animal caps (Figs. 6A,B). These results indicate that the competence of animal pole cells in response to ECD8 is different from the competence of ventral marginal zone cells.

It was shown previously that Xwnt8 synergizes with mesoderm inducing factors FGF and activin to induce dorsal mesoderm and elicit strong elongation movements in animal caps (Christian et al. 1992; Sokol and
Melton 1992). To test whether ECD8 has similar properties, we assessed its ability to modify the activity of mesoderm inducing factors. Despite the lack of effect on its own, ECD8 modulated the effect of activin and FGF on animal caps, although it behaved very differently from Xwnt8 (Christian et al. 1992; Sokol and Melton 1992). Whereas ECD8 activated muscle-specific actin expression in dissected ventral embryo halves (Fig. 4C), it inhibited muscle actin expression in activin-treated caps (Fig. 6B), further illustrating differences in competence of animal pole and ventral marginal zone cells. ECD8 also up-regulated the anterior neuroectodermal markers Xotx2 and XAG1 induced by activin (Fig.6B) and activated NCAM in FGF-treated animal caps (Fig. 6B). Thus, ECD8 promotes anterior development, consistent with the proposed posteriorizing role for Wnt signaling in anteroposterior axis formation (Itoh et al. 1995; McGrew et al. 1997).

\section{A role for Wnt ligands in dorsoventral patterning}

It is currently unknown which Wnt ligand is responsible for the suppression of dorsal development and is inhibited by ECD8. In parallel to our studies, a dominantnegative form of Xwnt8 was reported to inhibit ventral markers Xvent-1 and vox (Hoppler and Moon 1998). Although Xwnt8 is expressed in the ventrolateral mesendoderm and has a ventroposteriorizing activity (Christian and Moon 1993), several potent inhibitors of Xwnt8 (Hoppler et al. 1996; Sokol 1996; Finch et al. 1997; Leyns et al. 1997; Salic et al. 1997; Wang et al. 1997a; Glinka et al. 1998; Xu et al. 1998) fail to induce a secondary axis containing head structures. Other Wnt ligands, including Xwnt5a, Xwnt11, and Xwnt3a, are also expressed in the early embryo (Ku and Melton 1993; Moon et al. 1993; McGrew et al. 1997) and may be repressed by ECD8, but their potential role in the maintenance of ventral cell fates has not been analyzed (Moon et al. 1997). Interestingly, Xwnt3a mRNA, but not Xwnt8 or Xwnt5a mRNA, suppressed dorsoanterior development when overexpressed in dorsal blastomeres (Fig. 7A,B; data not shown). Because ECD8, but not Frzb (Wang et al. 1997b) or FrzA (Xu et al. 1998), can efficiently block the activities of Xwnt3a and Xwnt5a (Fig. 1), it may be a more potent inhibitor of various Wnt ligands than previously described FRPs. The unique ability of ECD8 to induce both head and axial mesoderm in ventral blastomeres clearly distinguishes it from other Wnt antagonists, such
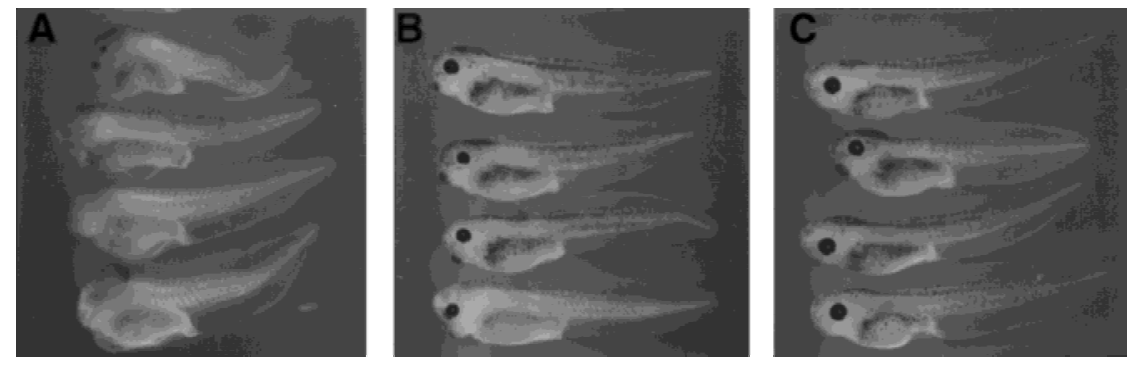

Figure 7. Inhibition of dorsoanterior development by Xwnt3a. Two animal dorsal blastomeres at four- to eight-cell embryos were injected with $4 \mathrm{pg}$ of $X w n t 3 a(A)$ or 2.5 pg of $X w n t 8$ mRNA $(B)$. Morphology of injected embryos is shown. $(C)$ Control siblings at comparable stage (stage 40). 
as Cerberus (Bouwmeester et al. 1996), Dkk-1 (Glinka et al. 1998), and WIF-1 (Wnt-inhibitory factor-1) (Hsieh et al. 1999|, and suggests the existence of yet undiscovered Wnt ligands.

Earlier studies have shown that inhibition of BMP4 signaling leads to partial axis induction (Graff et al. 1994; Suzuki et al. 1994). Together with these reports, our results argue that both BMPs and Wnt ligands act to suppress dorsal development and predict that inhibitors of ventralizing Wnt ligands and BMPs should cooperate in dorsoventral axis determination. Glinka et al. (1997) demonstrated that a combination of Wnt and BMP inhibitors leads to head induction and postulated the involvement of both pathways in anteroposterior patterning. Whereas our results do not contradict this model, they demonstrate that blocking Wnt signaling is sufficient on its own to induce a complete axis and trigger head development. Therefore, we propose that Wnt ligand(s) that are antagonized by ECD8 function to maintain ventral cell fates upstream of BMP signaling. It is also possible that multiple Wnt ligands function to reinforce BMP signaling during ventroposterior development. Because ECD8 up-regulated anterior markers in animal caps treated with mesoderm-inducing factors, some Wnt ligands may have an additional role in posteriorizing factors (Itoh et al. 1995; McGrew et al. 1997. Itoh and Sokol 1997). It remains to be seen whether the systems responsible for dorsoventral and anteroposterior patterning are interdependent and/or use the same molecular players.

\section{Materials and methods}

\section{Xenopus eggs and embryos}

Eggs were obtained from Xenopus females injected with 600 units of human chorionic gonadotropin, fertilized in vitro, and cultured in 0.1× MMR (Newport and Kirschner 1982). Embryonic stages were determined according to Nieuwkoop and Faber (1967).

\section{RNA microinjections and explant assays}

ECD8 construct in pXT7 vector (Dominguez et al. 1995) was generated by PCR from the Xfz8 plasmid (Itoh et al. 1998) and encodes the first 230 amino acids of the Xfz8 protein. BH1pXT7 is a control plasmid that encodes the first 434 amino acids of the Xfz8 protein. Capped synthetic RNAs were generated as described (Krieg and Melton 1984) by in vitro transcription of plasmids containing $E C D 8, X f z 8, B H 1$ (Itoh et al. 1998), Xwnt8 (Christian et al. 1991), Xwnt3a (Wolda et al. 1993), Xwnt5a (Moon et al. 1993), Xwnt2b (Landesman and Sokol 1997), Frzb1 (Leyns et al. 1997), CABR (Candia et al. 1997), $\beta$-galactosidase (Smith and Harland 1991), BMP4, and $t B R$ (Graff et al. 1994), by use of mMessage mMachine kits (Ambion). RNA microinjections were carried out as described (Itoh et al. 1995).

For animal cap assays, embryos were injected with mRNAs at the two-cell stage into animal pole region. Animal caps were isolated at stage 8 , cultured alone or in the presence of 100 $\mathrm{ng} / \mathrm{ml}$ Xenopus bFGF (Kimelman et al. 1988) or $5 \mathrm{ng} / \mathrm{ml}$ human recombinant activin A in 0.6× MMR and harvested for Northern analysis when control siblings reached stage 10.5, 12.5, or 25 . For analysis of marginal zone markers, embryos were injected with mRNAs into two ventrovegetal blastomeres at the four- to eight-cell stage and dissected into dorsal and ventral halves at stage 10. Total RNA was extracted from isolated embryo halves immediately or after their culture until the equivalent of stage 12.5 or 16

\section{Northern blot analysis}

Northern blot analysis was performed as described (Itoh et al. 1995). [ $\left.{ }^{32} \mathrm{P}\right]$ UTP-Labeled antisense RNA probes were prepared from plasmids, containing fibronectin (Krieg and Melton 1985), NCAM (Kintner and Melton 1987), XIF3 (Sharpe et al. 1989), EF1 (Krieg et al. 1989), and cardiac actin (Dworkin-Rastl et al. 1986) by in vitro transcription with SP6, T3, or T7 RNA polymerases (Krieg and Melton 1984). Other mesodermal markers, for which RNA probes were prepared, included Xwnt8 (Christian et al. 1991), Xlim1 (Taira et al. 1992), Xnr3 (Smith et al. 1995), gsc (Blumberg et al. 1991), Xotx2 (Pannese et al. 1995), chordin (Sasai et al. 1994), cerberus (Bouwmeester et al. 1996), frzb1 (Leyns et al. 1997), XANF1 (Zaraisky et al. 1995), PV.1 (Ault et al. 1996), Xbra (Smith et al. 1991), and myoD (Hopwood et al. 1989). DNA probe for XAG1 (Sive et al. 1989) was radiolabeled with $\left[{ }^{32} \mathrm{P}\right] \mathrm{dCTP}$ using random hexamer primers and the Klenow enzyme (Sambrook et al. 1989). After each hybridization, the membranes were stripped by boiling in distilled water. Every experiment was repeated at least three times.

\section{Luciferase activity measurements}

For luciferase assays, embryos were injected in the animal pole with 80 pg of Xvent2-luc DNA (Candia et al. 1997) and indicated mRNAs (Fig. 5C), and the luciferase activity was measured as described (Fan and Sokol 1997).

\section{Lineage tracing and histology}

Lineage tracing with $\beta$-galactosidase mRNA was carried out as described (Itoh et al. 1995). For histology, embryos were cultured until stages 33-39, fixed, dehydrated, embedded, and sectioned in Paraplast as described (Itoh et al. 1995). Sections were stained with hematoxylin/eosin. Sections of embryos stained for $\beta$-galactosidase were counterstained with eosin.

\section{Acknowledgments}

We thank E. Boncinelli, K. Cho, I. Dawid, E. De Robertis, J. Gurdon, R. Harland, M. Jamrich, D. Kimelman, D. Melton, R. Moon, H. Sive, and A. Zaraisky for plasmids and D. Luxenberg for activin. We are grateful to V. Krupnik, M. Fan, and J. Weber for critical comments on the manuscript. This work was supported by a Medical Foundation fellowship to K.I. and by grants from the March of Dimes Birth Defect Foundation and National Institutes of Health to S.S.

The publication costs of this article were defrayed in part by payment of page charges. This article must therefore be hereby marked 'advertisement' in accordance with 18 USC section 1734 solely to indicate this fact.

\section{References}

Ault, K.T., M.-L. Dirksen, and M. Jamrich. 1996. A novel homeobox gene $P V .1$ mediates induction of ventral mesoderm in Xenopus embryos. Proc. Nat1. Acad. Sci. 93: 6415-6420.

Blumberg, B., C.V.E. Wright, E.M. De Robertis, and K.W.Y. Cho. 1991. Organizer-specific homeobox genes in Xenopus laevis embryos. Science 253: 194-196. 
Bouwmeester, T., S.-H. Kim, Y. Sasai, B. Lu, and E.M. De Robertis. 1996. Cerberus is a head-inducing secreted factor expressed in the anterior endoderm of Spemann's organizer. Nature 382: 595-601.

Cadigan, K.M. and R. Nusse. 1997. Wnt signaling: A common theme in animal development. Genes \& Dev. 11:3286-3305.

Candia, A.F., T. Watabe, S.H.B. Hawley, D. Onichtchouk, Y. Zhang, R. Derynck, C. Niehrs, and K.W.Y. Cho. 1997. Cellular interpretation of multiple TGF $\beta$ signals: Intracellular antagonism between activin/BVg1 and BMP-2/4 signaling mediated by Smads. Development 124: 4467-4480.

Christian, J.L. and R.T. Moon. 1993. Interactions between Xwnt-8 and Spemann organizer signaling pathways generate dorsoventral pattern in the embryonic mesoderm of Xenopus. Genes \& Dev. 7: 13-28.

Christian, J.L., J.A. McMahon, A.P. McMahon, and R.T. Moon. 1991. Xwnt-8, a Xenopus Wnt-1/int-1-related gene responsive to mesoderm inducing growth factors, may play a role in ventral mesodermal patterning during embryogenesis. Development 111: 1045-1055.

Christian, J.L., D.J. Olson, and R.T. Moon. 1992. Xwnt-8 modifies the character of mesoderm induced by bFGF in isolated Xenopus ectoderm. EMBO I. 11: 33-41.

Cui, Y., J.D. Brown, R.T. Moon, and J.L. Christian. 1995. Xwnt8b: A maternally expressed Xenopus Wnt gene with a potential role in establishing the dorsoventral axis. Development 121: $2177-2186$

Deardorff, M.A., C. Tan, L.J. Conrad, and P.S. Klein. 1998. Frizzled-8 is expressed in the Spemann organizer and plays a role in early morphogenesis. Development 125: 2687-2700.

De Robertis, E.M. and Y. Sasai. 1996. A common plan for dorsoventral patterning in Bilateria. Nature 380: 37-40.

Dominguez, I., K. Itoh, and S.Y. Sokol. 1995. Role of glycogen synthase kinase $3 \beta$ as a negative regulator of dorsoventral axis formation in Xenopus embryos. Proc. Natl. Acad. Sci. 92: 8498-8502.

Dworkin-Rastl, E., D.B. Kelley, and M.B. Dworkin. 1986. Localization of specific mRNA sequences in Xenopus laevis embryos by in situ hybridization. I. Embryol. Exp. Morphol. 91: $153-168$

Fan, M.J. and S.Y. Sokol. 1997. A role for Siamois in Spemann organizer formation. Development 124: 2581-2589.

Finch, P.W., X. He, M.J. Kelley, A. Üren, R.P. Schaudies, N.C. Popescu, S. Rudikoff, S.A. Aaronson, H.E. Varmus, and J.S. Rubin. 1997. Purification and molecular cloning of a secreted, Frizzled-related antagonist of Wnt action. Proc. Nat1. Acad. Sci. 94: 6770-6775.

Glinka, A., W. Wu, D. Onichtchouk, C. Blumenstock, and C. Niehrs. 1997. Head induction by simultaneous repression of Bmp and Wnt signalling in Xenopus. Nature 389: 517-519.

Glinka, A., W. Wu, H. Delius, A.P. Monaghan, C. Blumenstock, and C. Niehrs. 1998. Dickkopf-1 is a member of a new family of secreted proteins and functions in head induction. Nature 391: 357-362.

Graff, J.M., R.S. Thies, J.J. Song, A.J. Celeste, and D.A. Melton. 1994. Studies with a Xenopus BMP receptor suggest ventral mesoderm-inducing signals override dorsal signals in vivo. Cell 79: 169-179.

Guger, K.A. and B.M. Gumbiner. 1995. $\beta$-catenin has Wnt-like activity and mimics the Nieuwkoop signaling center in Xenopus dorsal-ventral patterning. Dev. Biol. 172: 115-125.

Harland, R. and J. Gerhart. 1997. Formation and function of Spemann's organizer. Annu. Rev. Cell Dev. Biol. 13: 611667.

Heasman, J., A. Crawford, K. Goldstone, P. Garner-Hamrick, B. Gumbiner, P. McCrea, C. Kintner, C.Yoshida Noro, and C.
Wylie. 1994. Overexpression of cadherins and underexpression of $\beta$-catenin inhibit dorsal mesoderm induction in early Xenopus embryos. Cell 79: 791-803.

Hoppler, S. and R.T. Moon. 1998. BMP-2/-4 and Wnt-8 cooperatively pattern the Xenopus mesoderm. Mech. Dev. 71: 119-129.

Hoppler, S., J.D. Brown, and R.T. Moon. 1996. Expression of a dominant-negative Wnt blocks induction of MyoD in Xenopus embryos. Genes \& Dev. 10: 2805-2817.

Hopwood, N.D., A. Pluck, and J.B. Gurdon. 1989. MyoD expression in the forming somites is an early response to mesoderm induction in Xenopus embryos. EMBO J. 8: 3409-3417.

Hsieh, J.-C., L. Kodjabachian, M.L. Rebbert, A. Rattner, P.M. Smallwood, C. Harryman Samos, R. Nusse, I.B. Dawid, and J. Nathans. 1999. A new secreted protein that binds to Wnt proteins and inhibits their activities. Nature 398: 431-436.

Itoh, K. and S.Y. Sokol. 1997. Graded amounts of Xenopus dishevelled specify discrete anteroposterior cell fates in prospective ectoderm. Mech. Dev. 61: 113-125.

Itoh, K., T.L. Tang, B.G. Neel, and S.Y. Sokol. 1995. Specific modulation of ectodermal cell fates in Xenopus embryos by glycogen synthase kinase. Development 121: 3979-3988.

Itoh, K., J. Jacob, and S.Y. Sokol. 1998. A role for Xenopus Frizzled 8 in dorsal development. Mech. Dev. 74: 145-157.

Keller, R. 1991. Early embryonic development of Xenopus laevis. Methods Cell Biol. 36: 61-113.

Kimelman, D., J.A. Abraham, T. Haaparanta, T.M. Palisi, and M.W. Kirschner. 1988. The presence of fibroblast growth factor in the frog egg: Its role as a natural mesoderm inducer. Science 242: 1053-1056.

Kintner, C.R. and D.A. Melton. 1987. Expression of Xenopus $\mathrm{N}$-CAM RNA in ectoderm is an early response to neural induction. Development 99: 311-325.

Krieg, P.A. and D.A. Melton. 1984. Functional messenger RNAs are produced by SP6 in vitro transcription of cloned cDNAs. Nucleic Acids Res. 12: 7057-7070.

-1985. Developmental regulation of a gastrula-specific gene injected into fertilized Xenopus eggs. EMBO J. 4: 34633471.

Krieg, P.A., S.M. Varnum, W.M. Wormington, and D.A. Melton. 1989. The mRNA encoding elongation factor $1-\alpha(E F-1 \alpha)$ is a major transcript at the midblastula transition in Xenopus. Dev. Biol. 133: 93-100.

Ku, M. and D.A. Melton. 1993. Xwnt-11: A maternally expressed Xenopus wht gene. Development 119: 1161-1173.

Landesman, Y. and S.Y. Sokol. 1997. Xwnt-2b is a novel axisinducing Xenopus Wnt, which is expressed in embryonic brain. Mech. Dev. 63: 199-209.

Leyns, L., T. Bouwmeester, S.-H. Kim, S. Piccolo, and E.M. De Robertis. 1997. Frzb-1 is a secreted antagonist of Wnt signaling expressed in the Spemann organizer. Cell 88: 747-756.

Mayr, T., U. Deutsch, M. Kühl, H.C.A. Drexler, F. Lottspeich, R. Deutzmann, D. Wedlich, and W. Risau. 1997. Fritz: A secreted frizzled-related protein that inhibits Wnt activity. Mech. Dev. 63: 109-125.

McGrew, L.L., S. Hoppler, and R.T. Moon. 1997. Wnt and FGF pathways cooperatively pattern anteroposterior neural ectoderm in Xenopus. Mech. Dev. 69: 105-114.

McKendry, R., S.-C. Hsu, R.M. Harland, and R. Grosschedl. 1997. LEF-1/TCF proteins mediate Wnt-inducible transcription from the Xenopus nodal-related 3 promoter. Dev. Biol. 192: $420-431$.

Moon, R.T., R.M. Campbell, J.L. Christian, L.L. McGrew, J. Shih, and S. Fraser. 1993. Xwnt-5A: A maternal Wnt that affects morphogenetic movements after overexpression in embryos of Xenopus laevis. Development 119: 97-111. 
Moon, R.T., J.D. Brown, and M. Torres. 1997. WNTs modulate cell fate and behavior during vertebrate development. Trends Genet. 13: 157-162.

Newport, J. and M. Kirschner. 1982. A major developmental transition in early Xenopus embryos. I. Characterization and timing of cellular changes at the midblastula stage. Cell 30: 675-686.

Nieuwkoop, P.D. and J. Faber. 1967. Normal table of Xenopus laevis (Daudin). North Holland, Amsterdam, The Netherlands.

Pannese, M., C. Polo, M. Andreazzoli, R. Vignali, B. Kablar, G. Barsacchi, and E. Boncinelli. 1995. The Xenopus homologue of Otx2 is a maternal homeobox gene that demarcates and specifies anterior body regions. Development 121: 707-720.

Rattner, A., J.C. Hsieh, P.-M. Smallwood, D.J. Gilbert, N.G. Copeland, N.A. Jenkins, and J. Nathans. 1997. A family of secreted proteins contains homology to the cysteine-rich ligand-binding domain of frizzled receptors. Proc. Natl. Acad. Sci. 94: 2859-2863.

Salic, A.N., K.L. Kroll, L.M. Evans, and M.W. Kirschner. 1997. Sizzled: A secreted Xwnt8 antagonist expressed in the ventral marginal zone of Xenopus embryos. Development 124: 4739-4748.

Sambrook, J., E. F. Fritsch, and T. Maniatis. 1989. Molecular cloning: A laboratory manual, Cold Spring Harbor Laboratory Press, Cold Spring Harbor, NY.

Sasai, Y., B. Lu, H. Steinbeisser, D. Geissert, L.K. Gont, and E.M. De Robertis. 1994. Xenopus chordin: A novel dorsalizing factor activated by organizer-specific homeobox genes. Cell 79: 779-790.

Sharpe, C.R., A. Pluck, and J.B. Gurdon. 1989. XIF3, a Xenopus peripherin gene, requires an inductive signal for enhanced expression in anterior neural tissue. Development 107: 701714.

Sive, H.L., K. Hattori, and H. Weintraub. 1989. Progressive detemination during formation of the anteroposterior axis in Xenopus laevis. Cell 58: 171-180.

Smith, J.C., B.M.J. Price, J.B.A. Green, D. Weigel, and B.G. Herrmann 1991. Expression of a Xenopus homolog of Brachyury $(T)$ is an immediate-early response to mesoderm induction. Cell 67: 79-87.

Smith, W.C. and R.M. Harland. 1991. Injected Xwnt-8 RNA acts early in Xenopus embryos to promote formation of a vegetal dorsalizing center. Cell 67: 753-765.

- 1992. Expression cloning of noggin, a new dorsalizing factor localized to the Spemann organizer in Xenopus embryos. Cell 70: 829-840.

Smith, W.C., R. McKendry, S. Ribisi, Jr., and R.M. Harland. 1995. A nodal-related gene defines a physical and functional domain within the Spemann organizer. Cell 82: 37-46.

Sokol, S. 1996. Analysis of Dishevelled signalling pathways during Xenopus development. Curr. Biol. 6: 1456-1467.

- 1999. Wnt signaling and dorsoventral axis specification in vertebrates. Curr. Opin. Genet. Develop. 9: 405-410.

Sokol, S.Y. and D.A. Melton. 1992. Interaction of Wnt and activin in dorsal mesoderm induction in Xenopus. Dev. Biol. 154: 348-355.

Sokol, S., J.L. Christian, R.T. Moon, and D.A. Melton. 1991. Injected Wnt RNA induces a complete body axis in Xenopus embryos. Cell 67: 741-752.

Sokol, S.Y., J. Klingensmith, N. Perrimon, and K. Itoh. 1995. Dorsalizing and neuralizing properties of Xdsh, a maternally expressed Xenopus homolog of dishevelled. Development 121: $1637-1647$.

Suzuki, A., R.S. Theis, N. Yamaji, J.J. Song, J.M. Wozney, K. Murakami, and N. Ueno. 1994. A truncated bone morpho- genetic protein receptor affects dorsal-ventral patterning in the early Xenopus embryo. Proc. Natl. Acad. Sci. 91: 1025510259.

Taira, M., M. Jamrich, P.J. Good, and I.B. Dawid. 1992. The LIM domain-containing homeo box gene Xlim-1 is expressed specifically in the organizer region of Xenopus gastrula embryos. Genes \& Dev. 6: 356-366.

Thomsen, G.H. and D.A. Melton. 1993. Processed Vg1 protein is an axial mesoderm inducer in Xenopus. Cell 74: 433-441.

Wang, S., M. Krinks, K. Lin, F.P. Luyten, and M. Moos, Jr. 1997a. Frzb, a secreted protein expressed in the Spemann organizer, binds and inhibits Wnt-8. Cell 88: 757-766.

Wang, S., M. Krinks, and M. Moos, Jr. 1997b. Frzb-1, an antagonist of Wnt-1 and Wnt-8, does not block signaling by Wnts -3A, -5A, or -11. Biochem. Biophys. Res. Comm. 236: $502-$ 504.

Wolda, S.L., C.J. Moody, and R.T. Moon. 1993. Overlapping expression of Xwnt-3A and Xwnt-1 in neural tissue of Xenopus laevis embryos. Dev. Biol. 155: 46-57.

Xu, Q., P.A. D'Amore, and S.Y. Sokol. 1998. Functional and biochemical interactons of Wnts with FrzA, a secreted Wnt antagonist. Development 125: 4767-4776.

Zaraisky, A.G., V. Ecochard, O.V. Kazanskaya, S.A. Lukyanov, I.V. Fesenko, and A.-M. Duprat. 1995. The homeobox-containing gene XANF-1 may control development of the Spemann organizer. Development 121: 3839-3847. 


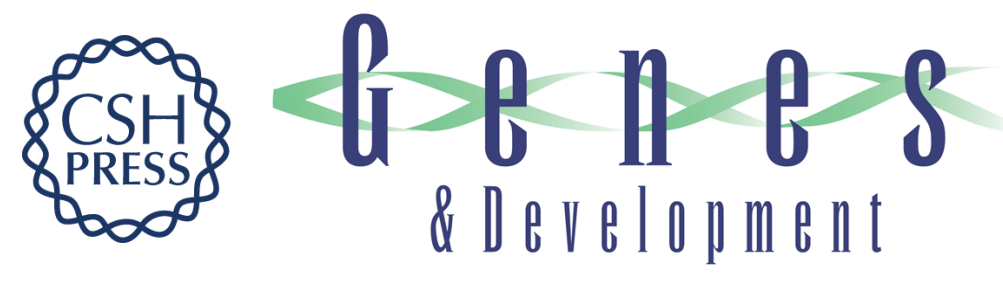

\section{Axis determination by inhibition of Wnt signaling in Xenopus}

Keiji Itoh and Sergei Y. Sokol

Genes Dev. 1999, 13:

References This article cites 66 articles, 26 of which can be accessed free at: http://genesdev.cshlp.org/content/13/17/2328.full.html\#ref-list-1

License

Email Alerting

Receive free email alerts when new articles cite this article - sign up in the box at the top Service right corner of the article or click here.

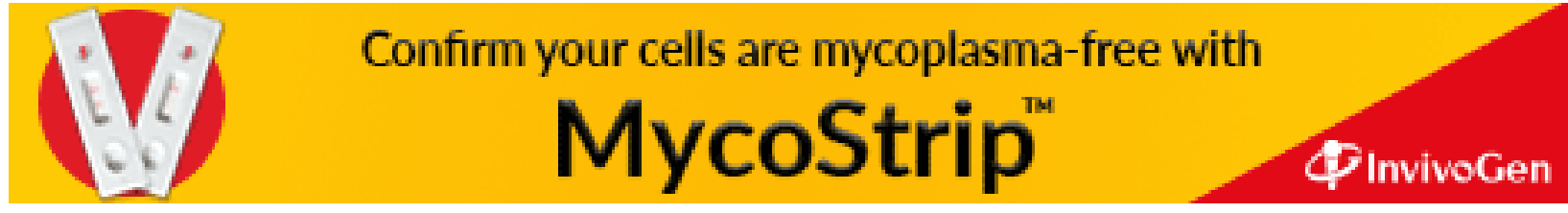

